\title{
Stimulation of Endorphin Neurotransmission in the Nucleus Accumbens by Ethanol, Cocaine, and Amphetamine
}

\author{
M. Foster Olive, ${ }^{1}$ Heather N. Koenig, ${ }^{1}$ Michelle A. Nannini, ${ }^{1}$ and Clyde W. Hodge ${ }^{2}$ \\ ${ }^{1}$ Department of Neurology and Ernest Gallo Clinic and Research Center, University of California at San Francisco, \\ Emeryville, California 94608, and ${ }^{2}$ Center for Alcohol Studies, School of Medicine, University of North Carolina at Chapel \\ Hill, Chapel Hill, North Carolina 27599
}

Numerous studies have demonstrated that drugs of abuse activate the mesolimbic dopamine reward pathway, and it is widely held that this activation contributes to the motivational and positive reinforcing properties of these substances. However, there is evidence that endogenous opioid systems within this brain reward circuit also play a role in drug reinforcement and drug-seeking behavior. Using microdialysis in freely moving rats, we sought to determine whether various drugs of abuse (i.e., ethanol, cocaine, D-amphetamine, and nicotine) would increase neurotransmission of endogenous opioid peptides (i.e., endorphins) in the nucleus accumbens. Drugs were ad-

The most well-characterized change in brain neurochemistry caused by drugs of abuse is an increase in extracellular dopamine levels in the nucleus accumbens (NAc) of the basal forebrain, and many lines of evidence suggest that this increase in dopamine release plays a role in the rewarding and positive reinforcing effects of drugs of abuse (for review, see Koob, 1992; Wise, 1998; Spanagel and Weiss, 1999). However, it has long been suspected that endogenous opioid peptides such as endorphins also play a role in drug reward, in positive reinforcement, and ultimately in the development of addiction. For example, early studies demonstrated that endogenous ligands of $\mu$ and $\delta$ opioid receptors, such as enkephalins and endorphins, possess intrinsic rewarding properties and will be self-administered by rodents directly into the brain ventricles (Belluzzi and Stein, 1977; van Ree et al., 1979) as well as regions of the mesolimbic reward system such as the NAc (Goeders et al., 1984). Along these lines, intracranial microinjections of enkephalins, endorphins, and other $\mu / \delta$ receptor agonists the NAc and other regions can produce conditioned place preference, a behavioral measure of reward and positive reinforcement (Olds, 1982; van der Kooy et al., 1982; Bals-Kubik et al., 1993). Finally, administration of $\mu$ and/or $\delta$ opioid receptor antagonists into the NAc can reduce appetitive behaviors and self-administration of certain drugs of abuse (Amalric et al., 1987; Corrigall and Vaccarino, 1988; Kelley et al., 1996; Heyser et al., 1999; Hyytia and Kiianmaa, 2001). Thus, $\mu / \delta$ opioid receptors in the NAc appear to be involved in the neurobiological mechanisms

\footnotetext{
Received July 10, 2001; revised Sept. 5, 2001; accepted Sept. 12, 2001.

This research was supported by funds from the State of California for medical research on alcohol and substance abuse through the University of California at San Francisco. We thank Hoa Lam and Nigel Maidment for technical advice on radioimmunoassay procedures.

Correspondence should be addressed to Dr. M. Foster Olive, Department of Neurology/Gallo Center, University of California at San Francisco, 5858 Horton Street, Suite 200, Emeryville, CA 94608. E-mail: folive@itsa.ucsf.edu.

Copyright (C) 2001 Society for Neuroscience 0270-6474/01/210001-06\$15.00/0
}

ministered intraperitoneally twice at $3 \mathrm{~h}$ intervals, and the endorphin content of microdialysates was analyzed by a solidphase radioimmunoassay. Acute administration of ethanol, cocaine, and D-amphetamine transiently elevated extracellular levels of endorphins in the nucleus accumbens, whereas nicotine and saline were without effect. We hypothesize that this drug-induced release of endorphins may contribute to the positive reinforcing and motivating properties of ethanol and psychostimulants.

Key words: microdialysis; endorphin; cocaine; ethanol; amphetamine; nicotine; addiction underlying drug reward and positive reinforcement. The present study was conducted to assess the ability of certain drugs of abuse (i.e., ethanol, cocaine, amphetamine, and nicotine) to alter extracellular levels of endogenous opioid ligands (endorphins) in the NAc using microdialysis sampling in freely moving animals.

\section{MATERIALS AND METHODS}

Animals. Male Long-Evans rats (250-400 gm, 10-20 weeks of age; Harlan, Madison, WI) were used as subjects. Animals were housed individually under a $12 \mathrm{hr}$ light/dark cycle with lights on at 6:00 A.M. Before surgical procedures, animals were housed in standard Plexiglas cages maintained at $25^{\circ} \mathrm{C}$ in a ventilated cage rack (Biozone Inc., Fort Mill, SC). After surgical procedures, animals were housed in clear cylindrical polycarbonate microdialysis cages $(30 \mathrm{~cm}$ diameter $\times 38 \mathrm{~cm}$ high; Instech Laboratories, Plymouth Meeting, PA) for the remainder of the experiments. Animals had access to food and water ad libitum throughout all procedures. All experiments were performed during the light portion of the light/dark cycle. All procedures were performed in accordance with approved institutional protocols, the 1996 National Research Council Guide for the Care and Use and Laboratory Animals, and the Society for Neuroscience Policy on the Use of Animals in Neuroscience Research.

Surgical procedures. Animals were anesthetized with $2 \%$ halothane vaporized in a 1:1 mixture of $\mathrm{O}_{2}$ and $\mathrm{N}_{2} \mathrm{O}$ and implanted with guide cannulas (SciPro, North Tonawanda, NY) aimed at the medial border of

This article is published in The Journal of Neuroscience, Rapid Communications Section, which publishes brief, peerreviewed papers online, not in print. Rapid Communications are posted online approximately one month earlier than they would appear if printed. They are listed in the Table of Contents of the next open issue of JNeurosci. Cite this article as: JNeurosci, 2001, 21:RC184 (1-5). The publication date is the date of posting online at www.jneurosci.org.

http://www.jneurosci.org/cgi/content/full/5844 
the core-shell region of the NAc [stereotaxic coordinates: anteroposterior, $+1.7 \mathrm{~mm}$; mediolateral, $-1.0 \mathrm{~mm}$ from bregma; dorsoventral, -6.0 $\mathrm{mm}$ from skull surface, according to the atlas of Paxinos and Watson (1997)]. Guide cannulas were secured with skull screws and dental cement. The wound was treated with $2 \%$ bacitracin and $2 \%$ xylocaine topical ointments and sutured closed with 3-0 vicryl sutures. After surgery, animals were allowed to recover in polycarbonate microdialysis cages for at least $5 \mathrm{~d}$ before dialysis probe implantation.

Microdialysis procedures. After recovery, animals were lightly reanesthetized as described above and implanted with microdialysis probes with $2 \mathrm{~mm}$ polyethylsulfone membranes (15 kDa cutoff; $0.6 \mathrm{~mm}$ outer diameter; SciPro) to a final depth of $-8.0 \mathrm{~mm}$ from skull surface. Probes were continuously perfused with artificial CSF (aCSF) containing 125 $\mathrm{mm} \mathrm{NaCl}, 2.5 \mathrm{~mm} \mathrm{KCl}, 0.5 \mathrm{~mm} \mathrm{NaH} \mathrm{PO}_{4} \cdot \mathrm{H}_{2} \mathrm{O}, 5 \mathrm{~mm} \mathrm{Na}_{2} \mathrm{HPO}_{4}, 1 \mathrm{~mm}$ $\mathrm{MgCl}_{2} \cdot 6 \mathrm{H}_{2} \mathrm{O}, 1.2 \mathrm{mM} \mathrm{CaCl}{ }_{2} \cdot 2 \mathrm{H}_{2} \mathrm{O}, 5 \mathrm{~mm}$ D-glucose, $0.2 \mathrm{~mm}$ L-ascorbic acid, and $0.025 \%(\mathrm{w} / \mathrm{v})$ bovine serum albumin, $\mathrm{pH}$ 7.3-7.5. All aCSF reagents were from Sigma (St. Louis, MO). Probes were attached to dual-channel liquid swivels (Instech Laboratories) with fluoroethylene polypropylene tubing (0.005 inch inner diameter; CMA/Microdialysis, North Chelmsford, MA) in cylindrical microdialysis cages to permit freely moving conditions. Animals were allowed to recover from probe implantation overnight before pharmacological experiments. On the following day, the aCSF flow rate was set at $2.0 \mu \mathrm{l} / \mathrm{min}$, and after a $1 \mathrm{~h}$ re-equilibration period, microdialysis samples were collected into polypropylene microcentrifuge tubes in a refrigerated microsampler (SciPro) at $30 \mathrm{~min}$ intervals. After collection, samples were immediately stored on dry ice and later frozen at $-70^{\circ} \mathrm{C}$ until analysis by radioimmunoassay (RIA).

Brain histology. After microdialysis procedures, animals were deeply anesthetized with Nembutal $(150 \mathrm{mg} / \mathrm{kg}$, i.p.) and perfused transcardially with $100 \mathrm{ml}$ of $0.9 \% \mathrm{NaCl}$ followed by $250 \mathrm{ml}$ of Streck tissue fixative (Streck Laboratories, La Vista, NE). Brains were then removed and placed in the same fixative for at least $48 \mathrm{~h}$ at $4^{\circ} \mathrm{C}$. Coronal brain sections (30 $\mu \mathrm{m}$ thickness) were cut on a cryostat (Leica, Deerfield, IL), mounted onto microscope slides, and coverslipped with Permount (Fisher Scientific, Santa Clara, CA). Probe placement was verified under light microscopy, and data from animals with probe placements outside of the target region were discarded.

Endorphin RIA. Microdialysate endorphin content was measured using a commercially available RIA kit (RK-022-33; Phoenix Pharmaceuticals, Mountain View, CA) adapted to solid-phase procedures (Olive and Hodge, 2001). Briefly, 96-well microtiter plates (Dynex Microlite 2+; Dynex Technologies, Chantilly, VA) were incubated with a protein A solution $\left(0.4 \mu \mathrm{g} / 50 \mu \mathrm{l}\right.$ in $\left.0.1 \mathrm{M} \mathrm{NaHCO}_{3}, \mathrm{pH} 9.0\right)$ for at least $24 \mathrm{~h}$ at $4{ }^{\circ} \mathrm{C}$ to facilitate binding of the antisera to the plate wells. Plates were then washed three times with assay buffer $\left[0.15 \mathrm{M} \mathrm{K}_{2} \mathrm{HPO}_{4}, 0.2 \mathrm{~mm}\right.$ ascorbic acid, $0.1 \%$ Tween 20 , and $0.1 \%$ gelatin (Sigma), pH 7.4, with phenol red added for enhanced visualization]. Next, plates were incubated with rabbit antisera to rat $\beta$-endorphin (50 $\mu \mathrm{l} /$ well; diluted 1:25 from stock in assay buffer) for $24 \mathrm{~h}$ at $4^{\circ} \mathrm{C}$. According to the manufacturer, this antiserum cross-reacts $100 \%$ with rat $\alpha$ - and $\beta$-endorphin, $60 \%$ with $\gamma$-endorphin, and $0 \%$ with met- and leu-enkephalin. After incubation with the antisera, plates were washed with assay buffer and incubated with $0-50 \mathrm{fmol} / 50 \mu \mathrm{l}$ (in quadruplicate) of the synthetic rat $\beta$-endorphin standards diluted in aCSF. Microdialysis samples $(50 \mu \mathrm{l})$ were also added at this time. Standards and samples were incubated at $4^{\circ} \mathrm{C}$ for $24 \mathrm{~h}$. Next, $\sim 5000 \mathrm{cpm} / 50 \mu \mathrm{l}$ of $\mathrm{I}^{125}$-labeled rat $\beta$-endorphin (diluted in assay buffer) was added to each well, and the plates were incubated at $4^{\circ} \mathrm{C}$ for $48 \mathrm{~h}$. Finally, plates were washed with assay buffer and $100 \mu \mathrm{l}$ of Microscint 40 scintillation fluid (Packard Instrument Company, Meriden, CT) was added to all wells. The plates were covered with TopSeal film, agitated for $1 \mathrm{~min}$ on an orbital shaker, and counted on a TopCount Microplate Scintillation Counter (Packard). Data from microdialysis samples falling outside of the linear range for this assay $(1-50 \mathrm{fmol} / 50 \mu \mathrm{l})$ were discarded.

Drugs. Cocaine hydrochloride, D-amphetamine sulfate, and nicotine hydrogen tartrate (Sigma) were dissolved in physiological saline and administered intraperitoneally in a volume of $1 \mathrm{ml} / \mathrm{kg}$. Ethanol $(95 \% \mathrm{v} / \mathrm{v})$ was diluted to $20 \% \mathrm{v} / \mathrm{v}$ in saline and administered intraperitoneally. All drugs were administered at 12:00 P.M. and 3:00 P.M. All drug studies were performed within $48 \mathrm{~h}$ of probe implantation. Only one drug was administered per day, and a subset of animals was administered saline as a control on the day after drug injections.

Data analysis. Baseline values of dialysate endorphin content (fmol/50 $\mu \mathrm{l})$ were analyzed across treatment groups using a one-way ANOVA.

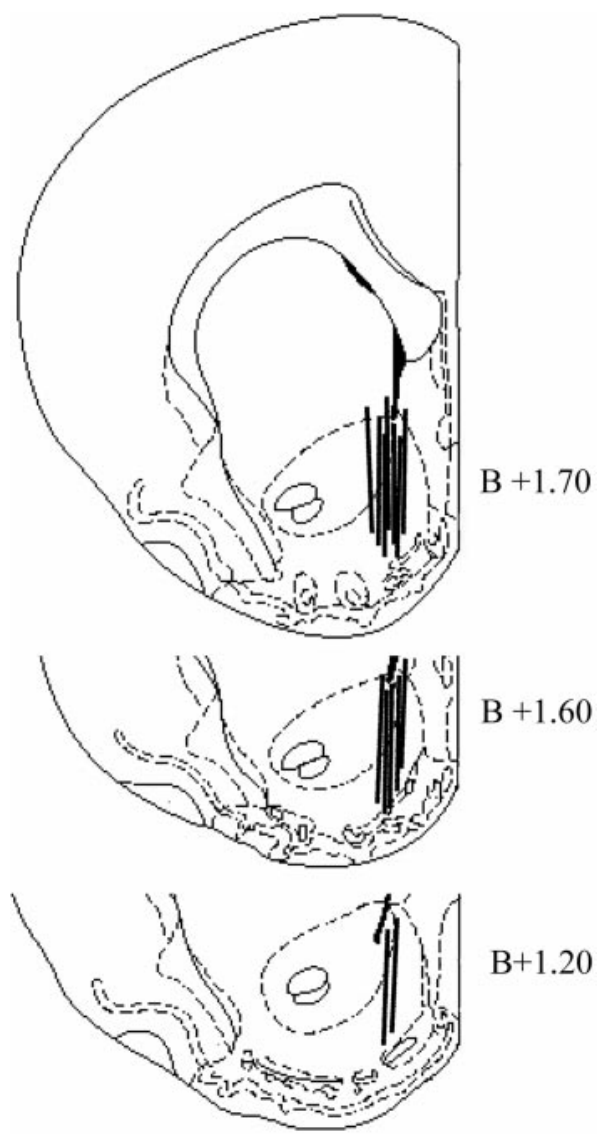

Figure 1. Diagram of coronal sections of rat brain indicating the location of dialysis probe placements along the medial core-shell border of the NAc. Vertical lines indicate the approximate location of the probe membrane derived from histological sections. Numbers indicate anterior distance (in millimeters) from bregma $(B)$. This figure was adapted from Paxinos and Watson (1997).

Next, for each animal, dialysate endorphin content was transformed into a percentage of basal endorphin release, assigning a value of $100 \%$ to the average endorphin level in the six $30 \mathrm{~min}$ baseline samples collected before drug administration. All data are presented as mean \pm SEM. Individual postinjection data points were compared with baseline values using a one-way repeated-measures ANOVA followed by a NewmanKeuls post hoc test or, when normality tests failed, a one-way ANOVA on ranks test.

\section{RESULTS}

As shown in Figure 1, the majority of dialysis probes were placed in the rostral core-shell border region of the NAc, between 1.2 and $1.7 \mathrm{~mm}$ anterior to bregma. The $\mathrm{IC}_{50}$ of the endorphin radioimmunoassay ranged from 6 to $8 \mathrm{fmol} / 50 \mu \mathrm{l}$, and the limit of detection was $\sim 1 \mathrm{fmol} / 50 \mu \mathrm{l}$ (Olive and Hodge, 2001).

Basal levels of dialysate endorphin content were $16.0 \pm 1.8$ $\mathrm{fmol} / 50 \mu \mathrm{l}($ mean $\pm \mathrm{SEM} ; n=40)$. No significant differences in basal endorphin levels were observed between individual treatment groups. The results of acute challenges with ethanol, cocaine, D-amphetamine, nicotine, or saline are shown in Figure 2. Acute administration of ethanol ( $2 \mathrm{gm} / \mathrm{kg}$, i.p.; $n=15)$ produced a significant increase in dialysate endorphin levels after the first injection (maximum $55 \pm 19 \%$ above baseline; $F_{(1,25)}=8.08 ; p<$ 0.05 ) and second injection (maximum $63 \pm 23 \%$ above baseline; $\left.F_{(1,20)}=6.76 ; p<0.05\right)$. Cocaine $(20 \mathrm{mg} / \mathrm{kg}$, i.p.; $n=10)$ also produced a significant increase in dialysate endorphin levels after the first injection (maximum $58 \pm 19 \%$ above baseline; $F_{(1,17)}=$ 

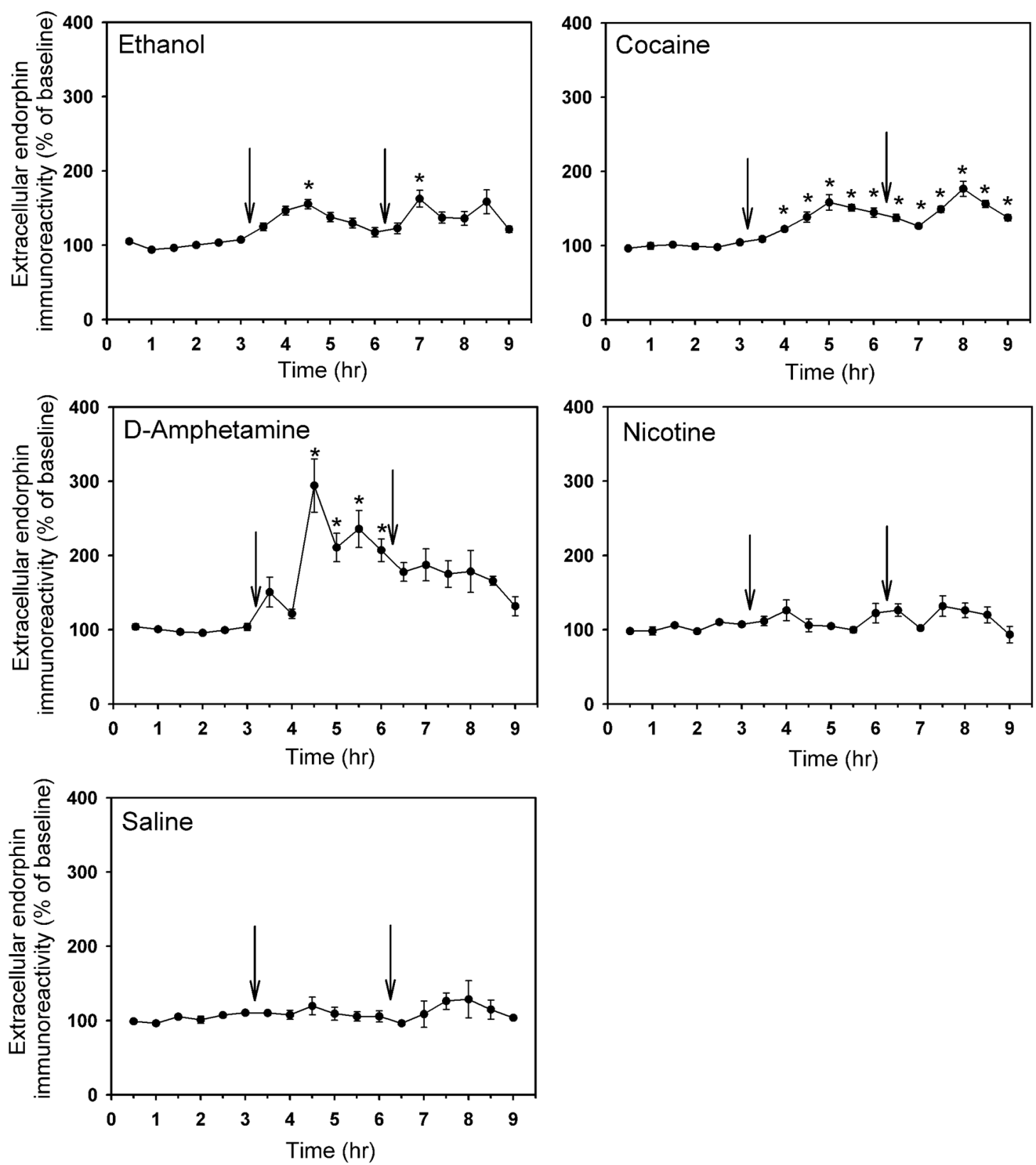

Figure 2. Effect of acute administration of ethanol $(2 \mathrm{gm} / \mathrm{kg}$, i.p.; $n=15)$, cocaine $(20 \mathrm{mg} / \mathrm{kg}$, i.p.; $n=10)$, D-amphetamine $(2 \mathrm{mg} / \mathrm{kg}$, i.p.; $n=7)$, nicotine $(2 \mathrm{mg} / \mathrm{kg}$, i.p.; $n=9)$, or saline $(n=8)$ on endorphin immunoreactivity in microdialysates from the rat NAc in vivo. Vertical arrows indicate when drugs were given. Each data point represents the mean \pm SEM of dialysate endorphin levels, expressed as a percentage of the average baseline value obtained in the six preinjection samples. ${ }^{*} p<0.05$ versus baseline.

6.16; $p<0.05$ ) and second injection (maximum $77 \pm 25 \%$ above baseline; $\left.F_{(1,18)}=9.24 ; p<0.05\right)$. Acute administration of D-amphetamine (2 $\mathrm{mg} / \mathrm{kg}$, i.p.; $n=7)$ produced a significant increase (maximum $160 \pm 65 \%$ above baseline; $F_{(1,15)}=6.01 ; p<$ 0.05 ) in dialysate endorphin content after the first injection; however, the second injection failed to produce a significant increase in dialysate endorphin levels. Nicotine $(n=9)$ or saline $(n=8)$ had no effect on dialysate endorphin levels after either injection.

\section{DISCUSSION}

These results demonstrate that ethanol, cocaine, and D-amphetamine increase extracellular levels of endorphins in the
NAc. Endorphins, particularly $\beta$-endorphin, are endogenous ligands of the $\mu$ opioid receptor that also display affinity for the $\delta$ opioid receptor (Raynor et al., 1994). Given previous studies demonstrating the positive reinforcing properties of $\mu$ and $\delta$ agonists when injected into this brain region (Olds, 1982; van der Kooy et al., 1982; Bals-Kubik et al., 1993), we hypothesize that this increase in extracellular endorphin levels may play a role in the reinforcing properties of these drugs of abuse. Recently, it was shown that acute exposure to $\Delta^{9}$-tetrahydrocannabinol results in an increase in extracellular enkephalins in the NAc (Valverde et al., 2001). In addition, previous work by our group has demonstrated an increase in extracellular enkephalin levels in the globus pallidus-ventral pallidum after acute exposure to opiates (Olive 
et al., 1995; Olive and Maidment, 1998) and has indicated that such increases are not observed in the NAc (Olive et al., 1995). Thus, the ability of drugs of abuse to engage endogenous opioid peptide systems in various brain reward regions may be drug- and site-specific. Additional studies examining the effects of ethanol, cocaine, and D-amphetamine on opioid peptide release in other reward-related brain regions such as the extended amygdala are currently underway.

Ethanol and cocaine were able to elicit an increase in extracellular endorphin levels in the NAc after both acute injections. However, D-amphetamine only elicited such an increase after the first injection. The reasons for the lack of effect of the second injection of D-amphetamine are currently unknown. A likely explanation is that the increased extracellular levels of endorphins arising from the first injection had not yet returned to basal levels at the time of the second injection. We have shown previously that drug-induced release of endogenous opioid peptides is highly dependent on preinjection basal levels, with higher basal extracellular levels correlating with blunted drug-induced increases in peptide release (Olive et al., 1995). A similar inverse relationship between preinjection extracellular neurotransmitter levels and the degree of drug-stimulated release has also been demonstrated with psychostimulant-induced increases in extracellular dopamine in the NAc (Weiss et al., 1992). Thus, drugstimulated endorphin release may be dependent on basal extracellular levels of this opioid peptide.

Along these lines, it is possible that circadian fluctuations in basal endorphin release may occur in the NAc and influence the degree of drug-induced increases in extracellular endorphin levels. Indeed, circadian variations in pituitary and plasma endorphin content have been documented (Kerdelhue et al., 1983; Millington et al., 1986). However, to our knowledge, a circadian pattern of endorphin levels in the NAc has not been demonstrated. Additional microdialysis studies examining diurnal fluctuations in extracellular endorphin levels in the NAc are needed to address this possibility.

The current study demonstrated a lack of effect of nicotine administration on extracellular endorphin levels. Although the reasons for the lack of effect of nicotine are unknown, these data argue against the possibility that drug-induced endorphin release is a result of stress attributable to the administration of the drug by the experimenter. The dose of nicotine used in the present study ( $2 \mathrm{mg} / \mathrm{kg}$, i.p.) has been shown to elevate plasma levels of adrenocorticotropin hormone (Weidenfeld et al., 1989) to levels similar to those observed after acute administration of ethanol (Rivier et al., 1984), cocaine (Moldow and Fischman, 1987), and D-amphetamine (Swerdlow et al., 1993). Thus, stress-induced activation of the hypothalamic-pituitary-adrenal axis caused by intraperitoneal drug administration is not likely a contributing factor to the increases in extracellular endorphin levels induced by ethanol and psychostimulants.

\section{Mechanisms of action}

The NAc and other limbic brain regions receive endorphinergic inputs from pro-opiomelanocortin (POMC)-containing neurons in the arcuate nucleus of the hypothalamus (Bloom et al., 1978; Finley et al., 1981). However, it is unclear whether the ethanoland psychostimulant-induced increases in extracellular NAc endorphin levels are a result of direct activation of the arcuate-NAc endorphin pathway. Some studies have shown that acute ethanol administration increases POMC mRNA in the arcuate nucleus (Rasmussen et al., 1998; Madeira and Paula-Barbosa, 1999), but other studies have demonstrated a lack of effect of acute ethanol on arcuate POMC mRNA content (Kinoshita et al., 2000). In addition, numerous studies have failed to find evidence of activation of arcuate POMC-containing neurons (as measured by immediate-early gene expression) by cocaine or D-amphetamine (for review, see Harlan and Garcia, 1998). Thus, a direct activation of the arcuate-NAc endorphin pathway by ethanol and psychostimulants, resulting in increased extracellular endorphin levels in the NAc, appears unlikely. The ability of ethanol and psychostimulants to increase the release of endorphins may be mediated via other heteroregulatory neurotransmitter systems in the NAc, such as dopamine, amino acids, or serotonin (Zangen et al., 1999).

\section{Implications for drug self-administration}

Numerous investigators have hypothesized that endorphin and other endogenous opioid systems are involved in addictive processes (Gianoulakis, 1996; van Ree, 1996; Herz, 1998; van Ree et al., 1999). Thus, our findings that ethanol, cocaine, and D-amphetamine increase extracellular levels of endorphins in the NAc have important implications for elucidating the neurobiological mechanisms by which opiate antagonists alter drug self-administration. For example, the opioid antagonist naltrexone is efficacious in reducing ethanol consumption in humans and animals (for review, see Johnson and Ait-Daoud, 2000; Kranzler, 2000), and recent evidence suggests that opioid antagonists may act within the NAc to exert their inhibitory effects on ethanol self-administration (Heyser et al., 1999). Thus, pharmacological blockade of the postsynaptic effects of endorphins after ethanolinduced release in the NAc may reduce the reinforcing and motivational properties of ethanol. However, opioid mechanisms in other brain regions such as the extended amygdala also likely contribute to the reinforcing properties of ethanol (Heyser et al., 1999).

Opioid antagonists can also attenuate self-administration of psychostimulants (Carroll et al., 1986; Mello et al., 1990; Corrigall and Coen, 1991; Ramsey and van Ree, 1991; Reid et al., 1995; Schmitz et al., 2001) as well as psychostimulant-induced conditioned place preference (Houdi et al., 1989; Trujillo et al., 1991; Menkens et al., 1992; Suzuki et al., 1994). Thus, endogenous opioid systems are also likely involved in the reinforcing properties of psychostimulants, and we hypothesize that the endorphin release in the NAc induced by cocaine and D-amphetamine contributes to their motivational and reinforcing properties. However, opioid peptide systems in other brain regions such as the ventral tegmental area may also play a role in the positive reinforcing effects of psychostimulants (Ramsey et al., 1999).

\section{Conclusions}

Drug abuse is a chronic disorder characterized by compulsive drug-seeking and drug self-administration behavior. However, the current study only investigated the acute effects of investigatoradministered ethanol, psychostimulants, and nicotine on extracellular endorphins in the NAc. Nonetheless, there is evidence that similar drug-induced increases in extracellular endorphins in the NAc will likely be observed in drug self-administering animals. Van Ree and colleagues documented that tissue levels of endorphins in the NAc of rats are decreased in anticipation of daily cocaine self-administration sessions (Sweep et al., 1988, 1989) with parallel increases in opioid receptor occupancy (Gerrits et al., 1999), indirectly indicating a release of these opioid peptides. Thus, additional in vivo studies are warranted to confirm such a release of 
endogenous opioids during drug self-administration, and ultimately to determine how endogenous opioid systems contribute to the development of drug addiction.

\section{REFERENCES}

Amalric M, Cline EJ, Martinez JL, Bloom FE, Koob GF (1987) Rewarding properties of $\beta$-endorphin as measured by conditioned place preference. Psychopharmacology 91:14-19.

Bals-Kubik R, Ableitner A, Herz A, Shippenberg TS (1993) Neuroanatomical sites mediating the motivational effects of opioids as mapped by the conditioned place preference paradigm in rats. J Pharmacol Exp Ther 264:489-495.

Belluzzi JD, Stein L (1977) Enkephalin may mediate euphoria and drive-reduction reward. Nature 266:556-558.

Bloom F, Battenberg E, Rossier J, Ling N, Guillemin R (1978) Neurons containing $\beta$-endorphin in rat brain exist separately from those containing enkephalin: immunocytochemical studies. Proc Natl Acad Sci USA 75:1591-1595.

Carroll ME, Lac ST, Walker MJ, Kragh R, Newman T (1986) Effects of naltrexone on intravenous cocaine self-administration in rats during food satiation and deprivation. J Pharmacol Exp Ther 238:1-7.

Corrigall WA, Coen KM (1991) Opiate antagonists reduce cocaine but not nicotine self-administration. Psychopharmacology 104:167-170.

Corrigall WA, Vaccarino FJ (1988) Antagonist treatment in nucleus accumbens or periaqueductal grey affects heroin self-administration. Pharmacol Biochem Behav 30:443-450.

Finley JC, Lindstrom P, Petrusz P (1981) Immunocytochemical localization of $\beta$-endorphin-containing neurons in the rat brain. Neuroendocrinology 33:28-42.

Gerrits MAFM, Wiegant VM, van Ree JM (1999) Endogenous opioids implicated in the dynamics of experimental drug addiction: an in vivo autoradiographic analysis. Neuroscience 89:1219-1227.

Gianoulakis C (1996) Implications of endogenous opioids and dopamine in alcoholism: human and basic science studies. Alcohol Alcohol 31 [Suppl 1]:33-42.

Goeders NE, Lane JD, Smith JE (1984) Self-administration of methionine enkephalin into the nucleus accumbens. Pharmacol Biochem Behav 20:451-455.

Harlan RE, Garcia MM (1998) Drugs of abuse and immediate-early genes in the forebrain. Mol Neurobiol 16:221-267.

Herz A (1998) Opioid reward mechanisms: a key role in drug abuse? Can J Physiol Pharmacol 76:252-258.

Heyser CJ, Roberts AJ, Schulteis G, Koob GF (1999) Central administration of an opiate antagonist decreases oral ethanol selfadministration in rats. Alcohol Clin Exp Res 23:1468-1476.

Houdi AA, Bardo MT, van Loon GR (1989) Opioid mediation of cocaine-induced hyperactivity and reinforcement. Brain Res 497:195-198.

Hyytia P, Kiianmaa K (2001) Suppression of ethanol responding by centrally administere CTOP and naltrindole in AA and Wistar rats. Alcohol Clin Exp Res 25:25-33.

Johnson BA, Ait-Daoud N (2000) Neuropharmacological treatments for alcoholism: scientific basis and clinical findings. Psychopharmacology 149:327-344

Kelley AE, Bless EP, Swanson CJ (1996) Investigation of the effects of opiate antagonists infused into the nucleus accumbens on feeding and sucrose drinking in rats. J Pharmacol Exp Ther 278:1499-1507.

Kerdelhue B, Karteszi M, Pasqualini C, Reinberg A, Mezey E, Palkovits M (1983) Circadian variations in $\beta$-endorphin concentrations in pituitary and in some brain nuclei of the adult male rat. Brain Res 261:243-248

Kinoshita H, Jessop DS, Finn DP, Coventry TL, Roberts DJ, Ameno K, Ijiri I, Harbuz MS (2000) Acute ethanol decreases NPY mRNA but not POMC mRNA in the arcuate nucleus. NeuroReport 11:3517-3519.

Koob GF (1992) Drugs of abuse: anatomy, pharmacology, and function of reward pathways. Trends Pharmacol Sci 13:177-184.

Kranzler HR (2000) Pharmacotherapy of alcoholism: gaps in knowledge and opportunities for research. Alcohol Alcohol 35:537-547.

Madeira MD, Paula-Barbosa MM (1999) Effects of alcohol on the synthesis and expression of hypothalamic peptides. Brain Res Bull 48:3-22.

Mello NK, Mendelson JH, Bree MP, Lukas SE (1990) Buprenorphine and naltrexone effects on cocaine self-administration by rhesus monkeys. J Pharmacol Exp Ther 254:926-939.

Menkens K, Bilsky EJ, Wild KD, Portoghese PS, Reid LD, Porreca F (1992) Cocaine place preference is blocked by the $\delta$-opioid receptor antagonist, naltrindole. Eur J Pharmacol 219:345-346.

Millington WR, Blum M, Knight R, Mueller GP, Roberts JL, O'Donohue TL (1986) A diurnal rhythm in proopiomelanocortin messenger ribonucleic acid that varies concomitantly with the content and secretion of $\beta$-endorphin in the intermediate lobe of the rat pituitary. Endocrinology 118:829-834.

Moldow RL, Fischman AJ (1987) Cocaine induced secretion of ACTH, $\beta$-endorphin, and corticosterone. Peptides 8:819-822.
Olds ME (1982) Reinforcing effects of morphine in the nucleus accumbens. Brain Res 237:429-440.

Olive MF, Hodge CW (2001) Sensitive radioimmunoassays for $\beta$-endorphin, $\mathrm{CRH}$, and substance $\mathrm{P}$ suitable for use with microdialysis. In: Monitoring molecules in neuroscience, Proceedings of the Ninth International Conference on In Vivo Methods (O'Connor WT, Lowry JP, O’Connor JP, O'Neill RD, eds), pp 29-30. Dublin: University College Dublin

Olive MF, Maidment NT (1998) Repeated heroin administration increases opioid peptide-like immunoreactivity in the globus pallidus/ ventral pallidum of freely moving rats. Psychopharmacology 139:251-254.

Olive MF, Bertolucci M, Evans CJ, Maidment NT (1995) Microdialysis reveals a morphine-induced increase in pallidal opioid peptide release. NeuroReport 6:1093-1096.

Paxinos G, Watson C (1997) The rat brain in stereotaxic coordinates. San Diego: Academic.

Ramsey NF, van Ree JM (1991) Intracerebroventricular naltrexone treatment attenuates acquisition of intravenous cocaine selfadministration in rats. Pharmacol Biochem Behav 40:807-810.

Ramsey NF, Gerrits MAFM, van Ree JM (1999) Naltrexone affects cocaine self-administration in naive rats through the ventral tegmental area rather than dopaminergic target regions. Eur Neuropsychopharmacol 9:93-99.

Rasmussen DD, Bryant CA, Boldt BM, Colasurdo EA, Levin N, Wilkinson CW (1998) Acute alcohol effects on opiomelanocortinergic regulation. Alcohol Clin Exp Res 22:789-801.

Raynor K, Kong H, Chen Y, Tasuda K, Yu L, Bell GI, Reisine T (1994) Pharmacological characterization of the cloned $\kappa^{-}, \delta$-, and $\mu$-opioid receptors. Mol Pharmacol 45:330-334.

Reid LD, Glick SD, Menkens KA, French ED, Bilsky EJ, Porreca F (1995) Cocaine self-administration and naltrindole, a $\delta$-selective opioid antagonist. NeuroReport 6:1409-1412.

Rivier C, Bruhn T, Vale W (1984) Effect of ethanol on the hypothalamic-pituitary-adrenal axis in the rat: role of corticotropinreleasing factor (CRF). J Pharmacol Exp Ther 229:127-131.

Schmitz JM, Stotts AL, Rhoades HM, Grabowski J (2001) Naltrexone and relapse prevention treatment for cocaine-dependent patients. Addict Behav 26:167-180.

Spanagel R, Weiss F (1999) The dopamine hypothesis of reward: past and current status. Trends Neurosci 22:521-527.

Suzuki T, Mori T, Tsuji M, Misawa M, Nagase H (1994) The role of $\delta$-opioid receptor subtypes in cocaine- and methamphetamine-induced place preferences. Life Sci 55:PL339-PL344.

Sweep CG, van Ree JM, Wiegant VM (1988) Characterization of $\beta$-endorphin-immunoreactivity in limbic brain structures of rats selfadministering heroin or cocaine. Neuropeptides 12:229-236.

Sweep CG, Wiegant VM, De Vry J, van Ree JM (1989) $\beta$-endorphin in brain limbic structures as neurochemical correlate of psychic dependence on drugs. Life Sci 44:1133-1140.

Swerdlow NR, Koob GF, Cador M, Lorang M, Hauger RL (1993) Pituitary-adrenal axis responses to acute amphetamine in the rat. Pharmacol Biochem Behav 45:629-637.

Trujillo KA, Belluzzi JD, Stein L (1991) Naloxone blockade of amphetamine place preference conditioning. Psychopharmacology $104: 265-274$

Valverde O, Noble F, Beslot F, Daugé V, Fournié-Zaluski M-C, Roques BP (2001) $\Delta^{9}$-tetrahydrocannabinol releases and facilitates the effects of endogenous enkephalins: reduction in morphine withdrawal syndrome without changes in rewarding effect. Eur J Neurosci 13:1816-1824.

van der Kooy D, Mucha RF, O'Shaughnessy M, Bucenieks P (1982) Reinforcing effects of brain microinjections of morphine revealed by conditioned place preference. Brain Res 243:107-117.

van Ree JM (1996) Endorphins and experimental addiction. Alcohol 13:25-30.

van Ree JM, Smyth DG, Colpaert FC (1979) Dependence creating properties of lipotropin $\mathrm{C}$-fragment ( $\beta$-endorphin): evidence for its internal control of behaviour. Life Sci 24:495-502.

van Ree JM, Gerrits MAFM, Vanderschuren LJMJ (1999) Opioids, reward, and addiction: an encounter of biology, psychology, and medicine. Pharmacol Rev 51:341-396.

Weidenfeld J, Bodoff M, Saphier D, Brenner T (1989) Further studies on the stimulatory action of nicotine on adrenocortical function in the rat. Neuroendocrinology 50:132-138.

Weiss F, Paulus MP, Lorang MT, Koob GF (1992) Increases in extracellular dopamine in the nucleus accumbens by cocaine are inversely related to basal levels: effects of acute and repeated administration. J Neurosci 12:4372-4380.

Wise RA (1998) Drug-activation of brain reward pathways. Drug Alcohol Depend 51:13-22.

Zangen A, Nakash R, Yadid G (1999) Serotonin-mediated increases in extracellular levels of $\beta$-endorphin in the arcuate nucleus and nucleus accumbens: a microdialysis study. J Neurochem 73:2569-2574. 